\title{
Quantifying Vegetation Change by Point Sampling Landscape Photography Time Series
}

\author{
Patrick E. Clark ${ }^{1}$ and Stuart P. Hardegree ${ }^{2}$ \\ Authors are ${ }^{1}$ Range Scientist and ${ }^{2}$ Supervisory Plant Physiologist, Northwest Watershed Research Center, \\ USDA Agricultural Research Service, Boise, ID 83712.
}

\begin{abstract}
Quantitative assessment of vegetation change is often conducted by digitally analyzing time series of aerial or vertical photography. Change analysis conducted using repeated oblique or landscape photography, however, has been limited to qualitative assessments. The purpose of this study was to develop sampling and analysis techniques for using a time series of digitized landscape photography to quantify vegetation change on rangeland landscapes. Digital images were created from black-and-white landscape photographs acquired in 1917, 1962, and 2000 near Whiskey Mountain in the Reynolds Creek Experimental Watershed of southwestern Idaho. Images were spatially registered to each other using control points and a polynomial transformation algorithm. Thirty random pixels along each of 30 random image lines were selected as point samples $(n=900)$ from within each image. The landscape feature represented in each selected pixel was classified into 1 of 15 cover types. Cover-type classification accuracy for the 2000 image was estimated to be $92.2 \%$ based on ground-truth data collected in the field. Classification accuracy was increased to $98.9 \%$ by combining rare or poorly separable cover-type classes. Image cover of vegetation cover types was quantified for each photography acquisition date. Changes in image cover of each cover type and direction of cover-type conversions were determined for each intervening time period. Analysis of image cover using repeated landscape photography is constrained by limitations imposed by oblique view angles and variable image quality. Repeat landscape photography, however, can be used to quantitatively assess long-term dynamics of vegetation cover on rangeland landscapes with visually distinct vegetation types.
\end{abstract}

\section{Resumen}

La evaluación cuantitativa del cambio de la vegetación a menudo es conducida por el análisis digital de series de tiempo de fotografías aéreas o verticales. El análisis de cambio usando fotografía oblicua repetida o de paisaje ha estado limitada a evaluaciones cualitativas. El propósito de este estudio fue desarrollar técnicas de muestreo y análisis para usar series de tiempo de fotografías de paisaje digitalizadas para cuantificar el cambio de vegetación en paisajes de pastizal. Se crearon imágenes digitales partir de fotografías de paisaje en blanco y negro adquiridas en 1917, 1962 y 2000 cerca de la montaña Whiskey en la Cuenca Hidrológica Experimental Reynolds Creek en el suroeste de Idaho. Las imágenes fueron registradas espacialmente una de otra usando puntos de control y un algoritmo de transformación polinomial. Como puntos de muestreo dentro de cada imagen se seleccionaron aleatoriamente 30 pixeles a lo largo de cada una de 30 líneas de imagen aleatorias $(n=900)$. La característica del paisaje representada en cada píxel seleccionado fue clasificada dentro de 1 de 15 tipos de cobertura. La exactitud de la clasificación por tipo de cobertura para las 2000 imágenes fue estimada en $92.2 \%$, basada en datos verdaderos colectados en campo. La exactitud de la clasificación aumentó a 98.9\% al combinar clases de tipo de cobertura raras o pobremente separables. La imagen de cobertura de los tipos de cobertura de vegetación fueron cuantificados para cada fecha de adquisición de las fotografías. Los cambios en la imagen de cobertura de cada tipo de cobertura y la dirección de las conversiones de tipo de cobertura fueron determinadas en cada período de tiempo que intervino. El análisis de las imágenes de cobertura usando la fotografía repetida del paisaje esta restringido por limitaciones impuestas por el ángulos de vista oblicuos y la calidad variable de la imagen. Sin embargo, la fotografía repetida de paisaje puede ser usada para evaluar cuantitativamente las dinámicas a largo plazo de la cobertura de vegetación de los paisajes de pastizal con tipos de vegetación visualmente distintos.

Key Words: cover-type conversion, digital image processing, ecology, image coregistration, image cover, oblique imagery

\section{INTRODUCTION}

Improving our understanding of how and when long-term vegetation changes have taken place is critical to developing a sound scientific basis for predicting the consequences of current range management. Vegetation change detection anal-

Correspondence: Patrick E. Clark, USDA-ARS, 800 Park Blvd, Suite 105 Boise, ID 83712. Email: pclark@nwrc.ars.usda.gov

Manuscript received 7 August 2004; manuscript accepted 27 July 2005. yses have often been conducted using time series of remote sensing imagery (e.g., Estes et al. 1982; Collins and Woodcock 1996; Lunetta and Elvidge 1999) but these analyses typically span time periods of less than 75 years. Historical landscape photography, acquired as early as the 1860 s and 1870 s, is available for many rangelands (Hart and Laycock 1996, see also Fig. 1). Repeat photography techniques have been used to create photographic time series from many of these early images (e.g., Ellison 1954; Blackburn and Tueller 1970; Blaisdell et al. 1982; Chadde and Kay 1991; Webb 1996; Skovlin et al. 2000). Unfortunately, we have lacked quantitative techniques for 
evaluating vegetation represented in these landscape photography time series. Consequently, although photographic records of more than 140 years of vegetation change exist, evaluations of these time series have always been merely qualitative in nature.

Although photogrammetric techniques and analyses exist for determining canopy or vertical vegetation cover from aerial photography (Lillesand and Kiefer 2000; Wolf and DeWitt 2000; Mikhail et al. 2001), it is essentially impossible to make this determination with landscape photography. Except in cases of extremely flat topography and/or where the camera point is well elevated above the subject terrain, view blockage by intervening terrain or tall vegetation and extreme variations in scaling within the imagery prohibit georectification and vertical canopy cover analysis. A new type of cover measure, consequently, is needed for analyzing vegetation change using landscape photography.

The objectives of this study were to introduce the concept of image cover as a measurement for quantifying vegetation changes within landscape photography time series and to develop image preparation, sampling and analysis techniques to evaluate long-term vegetation changes as represented by image-cover changes within these time series.

\section{MATERIALS AND METHODS}

\section{Study Area}

The study was conducted at Whiskey Mountain (lat $43^{\circ} 09^{\prime} \mathrm{N}$, long $\left.116^{\circ} 47^{\prime} \mathrm{W}\right)$ within the Reynolds Creek Experimental Watershed located $80 \mathrm{~km}$ south of Boise, in southwestern Idaho. Mean annual precipitation at the study area is about $400 \mathrm{~mm}$ (Hanson 2001) with about $75 \%$ falling as snow (Cooley et al. 1988). Estimated mean annual daily maximum, minimum, and mean air temperatures are $12.1^{\circ}, 3.7^{\circ}$, and $7.9^{\circ} \mathrm{C}$, respectively (Hanson et al. 2001).

Soils at Whiskey Mountain are steep and shallow, and form a complex of Takeuchi (coarse, loamy, mixed, frigid Typic Haploxerolls) and Kanlee (fine, loamy, mixed, frigid Typic Argixerolls) soil series (Stephenson 1977). Vegetation is composed of mountain big sagebrush (Artemisia tridentata Nutt. ssp. vaseyanna [Rydb.] Beetle), curl-leaf mountain mahogany (Cercocarpus ledifolius Nutt.), antelope bitterbrush (Purshia tridentata [Pursh] DC.), mountain snowberry (Symphoricarpus oreophilus Gray), green rabbitbrush (Chrysothamnus viscidiflorus [Hook.] Nutt.), serviceberry (Amelanchier alnifolia [Nutt.] Nutt. ex M. Roemer), rockspirea (Holodiscus dumosus [Nutt. ex Hook] Heller), native bunchgrasses and forbs, and some cheatgrass (Bromus tectorum L.). Western juniper (Juniperus occidentalis Hook.) is present as widely scattered, mature trees and more numerous juvenile trees which have not yet emerged above the big sagebrush canopy.

\section{Image Collection and Preparation}

The camera point used for landscape photographs acquired by Homer L. Shantz (Botany Dept., Univ. of Arizona, Tucson, AZ) on 10 September 1917 (Fig. 2, top) and by Freeman Smith (USDA-ARS, Northwest Watershed Research Center, Boise, ID) in 1962 (Fig. 2, center) was relocated in the field. On 12 September 2000 , a press-style, $10.2 \mathrm{~cm}$ by $12.7 \mathrm{~cm}$ (4 inch by 5 inch) format camera equipped with a $150 \mathrm{~mm}$ lens and 100
ASA color transparency film was used to rephotograph the view (Fig. 2, bottom). Care was taken so that the field of view and view angle used in the earlier photographs was duplicated as nearly as possible in the repeat photography.

Archived black-and-white prints $(10.2 \mathrm{~cm}$ by $12.7 \mathrm{~cm})$ of the 1917 and 1962 photography were used in this evaluation. Both prints were quite sharp and detailed, with complex shadow gradients suggesting that they were derived from the original negatives rather than duplicated from existing prints. The age and storage history of these prints, however, could not be determined from existing documentation. Film processing of the 2000 photography was done at a local commercial laboratory where a color contact print $(10.2 \mathrm{~cm}$ by $12.7 \mathrm{~cm})$ was produced. The 1917, 1962, and 2000 prints were all stored in archival-quality polyethylene sleeves, in the dark, and under stable temperature conditions until analyzed.

Prints from all 3 acquisition dates were scanned at 236 dots per $\mathrm{cm}$ with a flatbed scanner. The resulting digital images were saved as 8-bit, gray-scale bitmap files and imported into an image analysis software package (PCI version 6.3, PCI, Ltd.). Landscape features discernable in all the images, such as trees, large shrubs, and rocks, were identified as control points. A polynomial transformation utilizing the image sample and line values from these control points was used to spatially register the 1962 and 2000 images to the 1917 image (Richards and Jia 1999; Lillesand and Kiefer 2000). The 1962 image, having the narrowest field of view, was used as a template to crop the other images to a common field of view. This coregistration procedure resulted in a set of 3 digital images in which landscape features represented by individual image picture elements or pixels were located in the same sample/line coordinates in all 3 images (root mean square error $=0.73$ pixels).

\section{Problems with Traditional Cover Measures}

The term "cover," used without a qualifier, generally implies vertical cover. Vertical canopy cover is a measure representing the percentage of a horizontal plane or the ground surface that is intercepted by the vertical projection of the vegetation canopy (Daubenmire 1959; Bonham 1989). Vertical canopy cover can be measured using vertical, and in some cases, oblique aerial photography if the photography has been properly rectified using photogrammetric techniques. These techniques create a scaled representation or map of the earth's surface from aerial photographs. Rectifying aerial photography acquired at oblique view angles (i.e., large angular field of view) is a more complex and difficult process than that for vertical aerial photography (Mikhail et al. 2001). Landscape photography is ground-based and, consequently, is acquired at even more oblique view angles than oblique aerial photography. These extremely oblique views cause severe variations in the relative spatial scaling of features represented within landscape photography. In a digital landscape photography image, the ground sample distance (GSD) or distance on the ground represented by a background pixel is much greater than that of a pixel located in the image foreground (Fig. 3). These differences in GSD increase with increasingly oblique view angles (Richards and Jia 1999). Variable terrain within the landscape scene adds further complexity to the GSD represented within an image and typically also results in some degree of view blockage as well. Combined, these scaling and view 


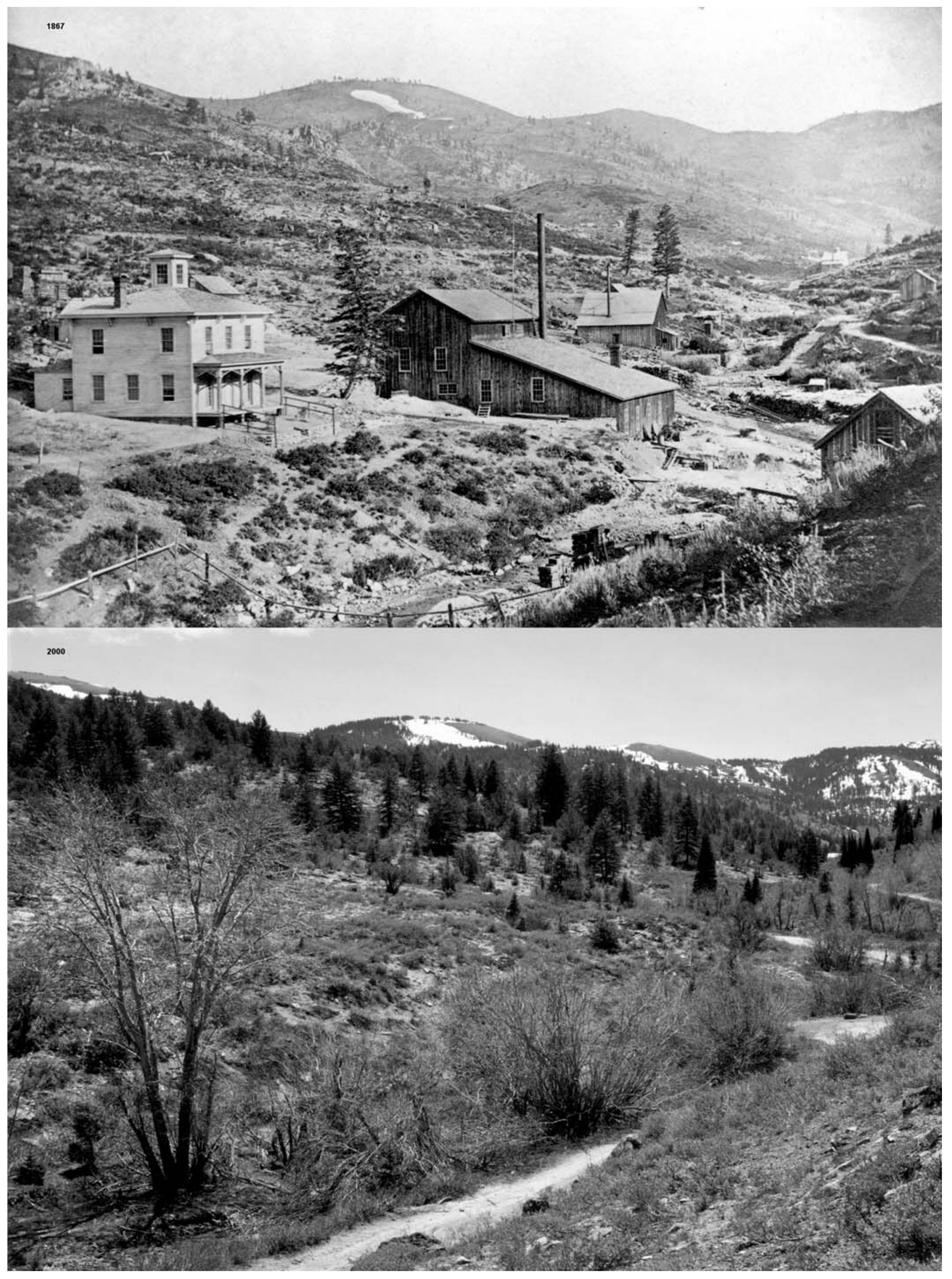


blockage effects make the use of photogrammetric techniques to rectify landscape photography essentially impossible. Consequently, traditional vegetation measures such as vertical canopy cover cannot be used to successfully quantify vegetation characteristics represented in landscape photography.

\section{Image Cover Defined}

Image cover is a new type of quantitative measure that we have devised to assess vegetation change represented within a landscape photography time series. A digital landscape photograph, like all digital images, is a 2-dimensional array of pixels. An image can, therefore, be considered a 2-dimensional object or surface. Individual pixels within or covering an image can be visually classified, using photograph interpretation techniques (Richards and Jia 1999; Lillesand and Kiefer 2000), into classes that represent different types of landscape features present on the ground within the photographic scene. Once the pixels in an image are classified, pixel counting or sampling can be used to determine or estimate the percentage of the image surface covered by pixels representing a specific feature cover type (e.g., mountain big sagebrush). Consequently, we have defined image cover as the percentage of pixels covering the surface of a digital landscape photograph that represent a specific cover type. Image cover can be determined by a ratio of the number of pixels of a specific cover type relative to the total number of pixels making up the image. Image cover, therefore, is a measurement of image surface coverage and not of ground surface coverage within the actual landscape. When conducted on a time series of imagery, sampling of image cover can also effectively identify and quantify the frequency of cover-type conversions or the changes in cover-type classification of individual pixels between different images of the series.

\section{Point Sampling for Image Cover}

Point sampling, where individual image pixels are considered points within the image, was used to determine image-cover percentages for the dominant vegetation types represented in each of the 3 images in the Whiskey Mountain time series. Because these images could not be properly rectified to the earth's surface, stratified random sampling was used to minimize sampling bias due to scaling inconstancy within each image. First, the image analysis software was used to randomly select 30 image lines (i.e., 30 rows of pixels) from each of the 3 images. Image lines from the 1917 image were randomly selected first, and then the line positions (i.e., row numbers) of these 30 lines were used to select 30 corresponding image lines from each of the 2 remaining images. Image lines were excluded from selection if they contained only sky pixels in all 3 images. Once selected, these image lines essentially represented 30 horizontal transects across each image. From each selected image line, 30 pixels were then randomly selected and treated as samples. Hence, a total of 900 corresponding pixels or samples were selected from each image for analysis.

Individual image lines were assumed to roughly represent lines of similar view angle and camera-to-subject distance within the landscape scene. Consequently, in the absence of extreme terrain variations, the GSD of pixels within individual image lines were assumed to be roughly similar. Stratified sampling utilizing individual image lines as strata should have minimized bias by restricting sampling to image pixel populations of relatively constant spatial scale. In simpler terms, stratification allowed vegetation represented by background pixels to receive the same sampling weight as that by foreground pixels.

Each of the 900 sample pixels per image were initially classified into 1 of 15 cover type classes after viewing the pixel and its neighbors at several levels of magnification using the image-processing software (Table 1). Pixel classification accuracy for the 2000 image was then assessed by field-checking a stratified random sample of 90 pixels drawn from the 900 total sample pixels for the image. Three sample pixels from each of the 30 image lines were randomly selected and the corresponding checkpoints were located in the field. Two people were required to locate the field checkpoints. One person (observer) stationed at the camera point with binoculars and a hard copy of the 2000 image used a 2-way radio to direct the other person (rover) to the checkpoint locations. Once at the checkpoint location, the observer directed the rover in marking the corners of the checkpoint as represented by the sample pixel. Although we did not devise a method to measure it, the spatial accuracy of marked checkpoints corners likely declined with increasing pixel GSD. After marking the checkpoint corners with plot pins or grade stakes and flagging, the rover moved to a nearby location where the check point could be viewed at close range. This view location was chosen using a hard copy of the 2000 image as a reference. The view location was selected to provide a view of the checkpoint with a bearing and view angle that was as similar as possible to that from the camera point. The rover then classified the vegetation within the checkpoint into 1 of the 15 cover-type classes. To determine the approximate GSD of the sample pixels, the rover also used the marked corners to measure the width of the checkpoint with a rule or survey tape. The checkpoint dimension data were then used to estimate the spatial scale represented by these 90 sample pixels from the 2000 imagery (Fig. 3). Scale of sample pixels within image lines spanning diverse terrain or areas with tall, intervening vegetation appeared to be more variable than those in lines spanning less diverse terrain. General trends in these data, however, appeared to support the assumption that stratified sampling based on image lines would tend to reduce sampling bias due to differences in pixel GSD. Although similar field data were not collected for the 1917 and 1962 images, limited comparisons of GSD for pixels representing stable rock outcrops in these images also supported the need to use stratified sampling.

The overall classification accuracy for the 15 cover-type classes $(92.2 \%$ correct $)$ was considered inadequate after the initial assessment. By combining 8 of the rare, or non-target, cover types into a single class, it was possible to elevate the classification accuracy for the resulting 7 classes (Table 1) to a more acceptable level (98.9\% correct). For subsequent analyses, it was assumed the classification accuracies of the 1917 and 1962 images were similar to that of the 2000 image.

Figure 1. Large-format landscape photography of the Cosmo Mill site near Silver City in southwestern Idaho. The top photograph was acquired in 1867 (photographer unknown). The bottom photograph was acquired by the lead author on 18 May 2000. 

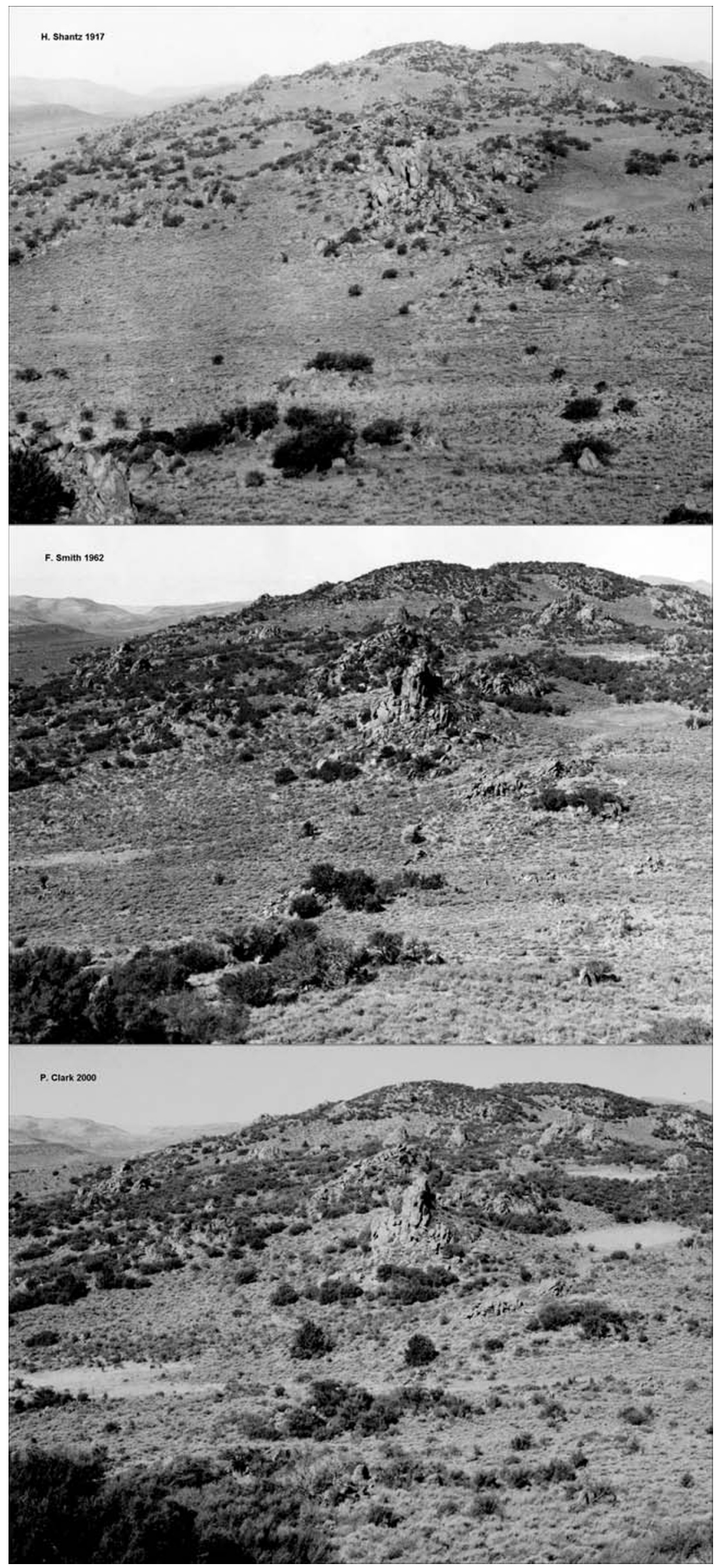


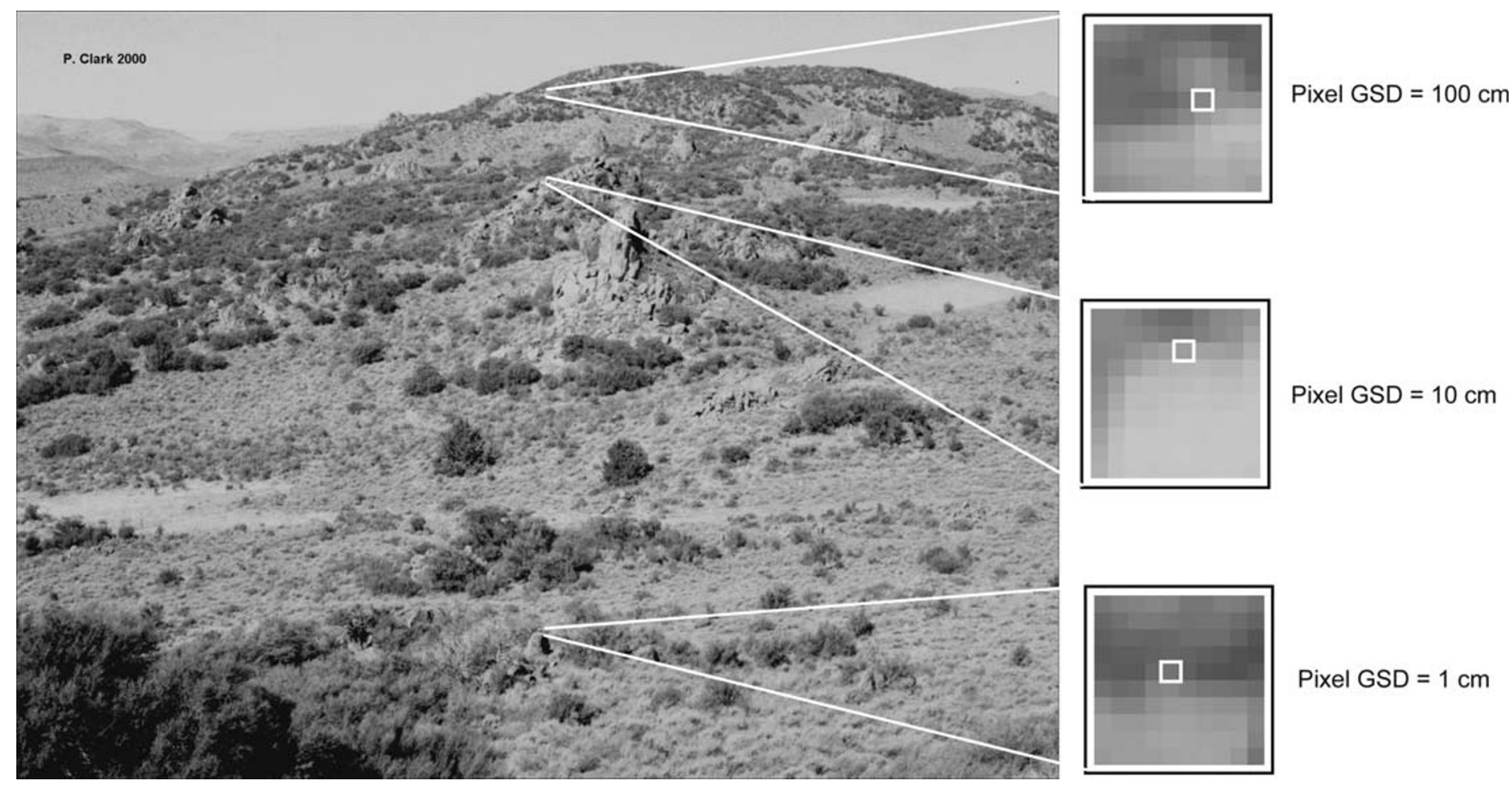

Figure 3. Large-format landscape photography, acquired 12 September 2000, of the Whiskey Mountain area within the Reynolds Creek Experimental Watershed in southwestern Idaho. The Ground Sample Distance (GSD) of selected foreground, midground, and background pixels, as determined by field measurement using an observer and rover, were $1 \mathrm{~cm}, 10 \mathrm{~cm}$, and $100 \mathrm{~cm}$, respectively.

For each selected image line or transect per image, image-cover percentages for each cover type were determined by dividing the number of pixels representing the cover type (0 to 30 pixels possible) by 30 , the total number of sampled pixels in the transect. Mean image cover percentages for each cover type were then calculated for each image based on the percent cover values from each of the 30 transects per image (Table 2). Differences in mean image-cover percentages were calculated by type for the 3 images and were used to assess image-cover changes that occurred during the 1917-1962, 1962-2000, and 1917-2000 time periods.

Frequencies of different kinds of cover type conversions (\%), where the cover type of a sample pixel changes to another cover type between images of a time series, were determined for each image transect. Mean cover-type conversion frequencies for each of the 3 periods were calculated, by kind of conversion, using the conversion frequency values determined for the image transects (Table 3).

\section{Statistical Procedures}

Differences in image cover were evaluated using mixed-model analysis of variance under a 2-factor repeated-measures design (Proc Mixed) (SAS 1999). Year $(\mathrm{df}=2)$ and cover type $(\mathrm{df}=6)$ were treated as fixed effects and transect $(\mathrm{df}=29)$ and its interactions with year and cover type were treated as random effects. Percentage cover by different cover types could vary per transect, consequently, cover-type-transect combinations were treated as subjects in this repeated measures design. Year and cover type and their interaction were tested with the residual error term. Where significant effects were detected, the Bonferroni procedure was used for mean separations at the 0.05 level of significance.

Differences in the frequency of cover-type conversions were also investigated using a separate mixed-model analysis of variance under a 2-factor repeated measures design. Fixed effects in the design were period $(\mathrm{df}=1)$ and conversion type $(\mathrm{df}=48)$; transect $(\mathrm{df}=29)$ and its interactions with period and conversion type were considered random effects. Frequency of cover-type conversions could vary by conversion type within a transect, thus, combinations of conversion types and transects were treated as subjects in this repeated measure design. Period and conversion type and their interaction were tested with the residual error term. Where significant effects were detected, the Bonferroni procedure was used for mean separations at the 0.05 level of significance.

\section{RESULTS}

\section{Accuracy Assessment}

Initial classification accuracy for the 2000 image was $92.2 \%$. Two pixels classified as rockspirea were actually green rabbitbrush and 1 mountain snowberry pixel, 3 western juniper pixels,

Figure 2. Large-format landscape photography of the Whiskey Mountain area within the Reynolds Creek Experimental Watershed in southwestern Idaho. The top photograph was acquired on 10 September 1917 by Homer L. Shantz. The center photograph was acquired by Freeman Smith in 1962. The bottom photograph was acquired by the lead author on 12 September 2000. 
Table 1. Cover types initially used to classify landscape features identified in digital images created from repeat photography acquired in 1917, 1962, and 2000 of the Whiskey Mountain area in southwestern Idaho.

\begin{tabular}{|c|c|}
\hline Cover types & Description \\
\hline Antelope bitterbrush & Purshia tridentata excluding dead wood \\
\hline Grass & Grasses, forbs, and standing herbaceous litter \\
\hline Green rabbitbrush ${ }^{1}$ & Chrysothamnus viscidiflorus excluding dead wood \\
\hline Mountain big sagebrush & $\begin{array}{l}\text { Artemisia tridentata ssp. vaseyanna excluding } \\
\text { dead wood }\end{array}$ \\
\hline Mountain mahogany & Cercocarpus ledifolius excluding dead wood \\
\hline Mountain snowberry ${ }^{1}$ & Symphoricarpus oreophilus excluding dead wood \\
\hline Serviceberry ${ }^{1}$ & Amelanchier alnifolia excluding dead wood \\
\hline Rockspirea $^{1}$ & Holodiscus dumosus excluding dead wood \\
\hline Western juniper $^{1}$ & Juniperus occidentalis excluding dead wood \\
\hline Wood $^{1}$ & Standing dead and down wood ( $>1 \mathrm{~cm}$ diameter) \\
\hline Bare ground & Bare ground and litter ( $<1 \mathrm{~cm}$ diameter) \\
\hline Rock & Rock outcrops, boulders, cobbles, and pebbles \\
\hline Background $^{1}$ & $\begin{array}{l}\text { Distant landscapes where other cover types could } \\
\text { not be discerned }\end{array}$ \\
\hline Sky ${ }^{1}$ & Sky showing between peaks in the horizon \\
\hline Other & All other cover types \\
\hline
\end{tabular}

${ }^{1}$ Features initially classified as western juniper, mountain snowberry, green rabbitbrush, serviceberry, rockspirea, wood, background, and sky cover were later reclassified into the Other class reducing total classes used for statistical analysis from 15 to 7 .

and 1 antelope bitterbrush pixel were actually serviceberry. All 7 misclassified pixels were located in small areas of the image where the gray-scale values representing these target features were similar to that of the surrounding soil or rock background. Much of the true outline of these target features, consequently, was indiscernible from soil and rock, thus complicating classification. The rockspirea, green rabbitbrush, mountain snowberry, western juniper, and serviceberry classes individually contributed very little to the total image cover and their rarity greatly complicated the statistical analysis. Consequently, these 5 classes were reclassified along with the wood, background, and sky classes into the "Other" class (Table 1). Compositing the original 15 classes to form 7 resultant classes elevated the overall classification accuracy of the 2000 image to $98.9 \%$.

\section{Image Cover Changes}

Image point sampling and analysis revealed that mountain big sagebrush dominated the image cover of Whiskey Mountain in the 1917 and 1962 images, and was codominant with mountain mahogany in the 2000 image (Table 2). Antelope bitterbrush was the least common image-cover type throughout the entire 83-year period.

Mountain mahogany was the most dynamic image cover type, increasing by 12.7 and 8.4 percentage points during the 1917-1962 and 1962-2000 periods, respectively (Table 2). Image-cover by bare ground and rock declined by 9.2 and 9.0 percentage points, respectively, between 1917 and 1962 . Image cover of antelope bitterbrush increased by 3.7 percentage points and mountain big sagebrush image cover decreased by 8.7 percentage points between 1962 and 2000. Image cover of the grass and "other" classes remained unchanged between 1917 and 2000.
Table 2. Percentage cover of digital images by 7 cover types at the Whiskey Mountain area of southwestern Idaho, created from repeat photography acquired in 1917, 1962, and 2000 based on stratified random sampling of 900 pixels per image.

\begin{tabular}{|c|c|c|c|}
\hline \multirow[b]{2}{*}{ Cover type $^{1}$} & \multicolumn{3}{|c|}{ Sampling years } \\
\hline & 1917 & 1962 & 2000 \\
\hline & \multicolumn{3}{|c|}{ 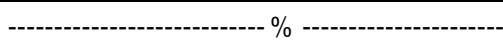 } \\
\hline Mountain big sagebrush & $39.6 \mathrm{a} \chi \psi^{2,3}$ & $43.3 a \psi$ & $34.6 \mathrm{a} \chi$ \\
\hline Rock & $20.7 b \chi$ & $11.7 b \psi$ & $10.2 b \psi$ \\
\hline Bare ground & $14.4 \mathrm{bc} \chi$ & $5.2 \mathrm{c} \psi$ & $3.7 \mathrm{c} \psi$ \\
\hline Mountain mahogany & $10.1 \mathrm{~cd} \chi$ & $22.8 \mathrm{~d} \psi$ & $31.2 \mathrm{a} \omega$ \\
\hline Grass & $6.8 \mathrm{df} \chi$ & $8.0 \mathrm{bc} \chi$ & $5.6 c \chi$ \\
\hline Antelope bitterbrush & $0.7 \mathrm{e} \chi$ & $0.4 \mathrm{e} \chi$ & $4.1 \mathrm{c} \psi$ \\
\hline Other & $7.8 f \chi$ & $8.6 \mathrm{c} \chi \psi$ & $10.7 b c \psi$ \\
\hline
\end{tabular}

${ }^{1}$ Pixels initially classified as green rabbitbrush, mountain snowberry, serviceberry, rockspirea, western juniper, wood, background, and sky cover were reclassified into the Other class for statistical analysis.

${ }^{2}$ Percentage values with different letter codes within columns were significantly different at the 0.05 level.

${ }^{3}$ Percentage values with different Greek letter codes within rows were significantly different at the 0.05 level.

\section{Cover-type Conversions}

Cover-type conversions occurred at $55.4 \%$ of the 900 sampling points between 1917 and 2000. Conversions from mountain big sagebrush and rock to mountain mahogany and from bare ground to mountain big sagebrush were the most common cover-type conversions during this 83 -year period (Table 3 ). Image cover dynamics for the 1917-1962 and 1962-2000 intervals were similar $(P=0.91)$. Cover-type conversions occurred at $43.8 \%$ of the sampling points between 1917 and 1962 and at $40.7 \%$ of the sampling points between 1962 and 2000 . The frequency of some cover-type conversions, however, differed between time periods. Expansion of mountain mahogany image cover between 1917 and 1962 occurred primarily at the expense of rock and mountain big sagebrush pixels. Loss of rock pixels to mountain mahogany decreased during 1962-2000 and conversions from mountain big sagebrush to mountain mahogany pixels increased relative to the 1917-1962 period (Table 3). Conversions from bare-ground pixels to mountain big sagebrush, grass, and mountain mahogany occurred primarily between 1917 and 1962. Mountain big sagebrush conversions to antelope bitterbrush pixels took place mostly during 1962-2000.

\section{DISCUSSION}

\section{Contrasting Aerial and Landscape Photography}

Landscape-scale vegetation assessments are now typically conducted using remote sensing data such as digitized aerial photography or satellite imagery. These data are usually acquired at nadir or near nadir, meaning the camera or sensor is directly overhead and the view angle is nearly perpendicular to the land surface. Imagery acquired at nadir can be georectified and resampled (i.e., essentially converted to maps) quite easily using techniques now routine in photogrammetry (Lillesand and Kiefer 2000; Wolf and DeWitt 2000; Mikhail et al. 2001). Once the imagery is georeferenced, features observed in the imagery are actually scaled, 2-dimensional representations of the real features on the landscape. 
Table 3. The 10 most common cover-type conversions occurring in the Whiskey Mountain area of southwestern Idaho between 1917 and 2000 and during the 1917-1962 and 1962-2000 intermediate time periods, based on stratified random sampling of digital images (900 pixels $\cdot$ image $^{-1}$ ) created from repeat photography acquired in early September of 1917, 1962, and 2000.

\begin{tabular}{|c|c|c|c|}
\hline \multirow{2}{*}{$\begin{array}{l}\text { Change of direction between } \\
\text { cover types }\end{array}$} & \multicolumn{3}{|c|}{ Periods } \\
\hline & $1917-2000$ & 1917-1962 & $1962-2000$ \\
\hline & \multicolumn{3}{|c|}{ 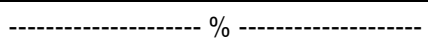 } \\
\hline \multicolumn{4}{|l|}{ Mountain big sagebrush to } \\
\hline Mountain mahogany & $10.1 a^{1,2}$ & $5.9 a b \chi^{3}$ & $8.8 \mathrm{a} \psi$ \\
\hline Rock to mountain mahogany & $9.2 \mathrm{a}$ & 7.7a $\chi$ & $2.4 \mathrm{~b} \psi$ \\
\hline Bare ground to mountain big sagebrush & $6.8 \mathrm{ab}$ & 7.1ab $\chi$ & $2.7 \mathrm{~b} \psi$ \\
\hline Bare ground to mountain mahogany & $4.4 b c$ & $2.0 \mathrm{c} \chi$ & $0.9 \mathrm{c} \psi$ \\
\hline Grass to mountain big sagebrush & $3.2 \mathrm{~cd}$ & $3.8 \mathrm{bc} \chi$ & 4.1b $\chi$ \\
\hline \multicolumn{4}{|l|}{ Mountain big sagebrush to } \\
\hline Antelope Bitterbrush & $2.8 \mathrm{~cd}$ & $0.1 \mathrm{~d} \chi$ & $2.6 \mathrm{~b} \psi$ \\
\hline Mountain big sagebrush to bare ground & 2.0de & $1.7 \mathrm{c} \chi$ & $2.2 \mathrm{~b} \chi$ \\
\hline Bare ground to grass & 2.0de & $2.10 \chi$ & $0.9 \mathrm{c} \psi$ \\
\hline Rock to mountain big sagebrush & 2.0de & $2.2 \mathrm{c} \chi$ & $0.8 \mathrm{c} \psi$ \\
\hline Mountain big sagebrush to grass & $1.4 \mathrm{e}$ & $3.2 c \chi$ & $3.2 \mathrm{~b} \chi$ \\
\hline
\end{tabular}

${ }^{1}$ The 3 most common cover-type conversions within each period are denoted with bold text.

${ }^{2}$ Percentage values with different letter codes within columns were significantly different at the 0.05 level.

${ }^{3}$ Percentage values with different Greek letter codes within rows of the 1917-1962 and 1962-2000 columns were significantly different at the 0.05 level.

Computer-automated techniques can then be applied to the imagery to classify pixels representing features, such as individual plants or vegetation stands, into corresponding species or plant community categories (Richards and Jia 1999). These georeferenced/classified images can then be used to determine vertical cover or other attributes commonly used to evaluate rangeland vegetation. Remotely sensed vertical cover estimates can also be easily reconciled with ground-truth measurements collected using point frame, line intercept, and other field techniques for assessing cover. Repeated remote sensing overflights of a landscape can be used to form a time series of georeferenced and classified imagery. Analysis of remote sensing time series is a well-established and powerful means of detecting temporal changes in vegetation at the landscape scale. Unfortunately, for most rangelands of the world, aerial photography coverage extends back no further than the 1930s. Consequently, change-detection analyses based on these data are limited to about the last 70 years, which is a fairly short time span in ecological terms.

In contrast, landscape photographs date back to the 1860s. Historical landscape photography is available for almost every rangeland vegetation type or representative landscape (e.g., Biswell 1963; Cable 1973; Martin and Turner 1977; Houston 1982; Gruell 1983; Humphrey 1987; Williams et al. 1987; Skovlin and Thomas 1995; Hart and Laycock 1996; Jackson et al. 1999). Time series created with landscape photography of rangelands could potentially reveal more than 145 years of vegetation change (Fig. 1). Landscape photographs, however, are typically acquired from ground-based camera points at highly oblique view angles. These oblique angles commonly result in view blockage by intervening terrain or vegetation, thus preventing a map-like or bird's-eye view of the landscape. Oblique view angles also cause considerable panoramic distortion (Richards and Jia 1999) thus resulting in large variability in scale within a landscape photograph. Features in the background regions of a landscape photograph are represented in smaller scale than features in foreground regions. Combined, view blockage and large variability in scale make it impossible to analyze landscape photography using techniques designed for vertical view angles. Lack of appropriate analytic tools has precluded researchers and natural resource managers from attempting to quantify vegetation change represented within landscape photography. Rather, the typical approach has been to just visually compare the original and repeat photographs in an effort to detect gross differences such as the relative location and perceived extent of different vegetation types. Although these visual comparisons can be powerful, particularly for documenting massive vegetation changes due to natural succession or extensive disturbance, this approach is quite subjective and unsatisfying.

\section{Dealing with Scale Variability}

As noted above, a principal obstacle to quantifying vegetation change from landscape photography time series has been scale variability within these oblique images. We reduced the scalevariability bias by stratified sampling of image pixels using image lines as strata. The theory behind this stratification approach is presented here. If a line representing equal subject-to-camera distance were drawn across a landscape photograph, the line would curve somewhat due to lens distortion and increasing lateral distance from the camera but would generally run horizontally across the photograph. The line would also exhibit some degree of sinuosity depending on the complexity of the terrain and the structure of the vegetation within the scene. Still, in cases of moderately diverse terrain and vegetation, the equal camerato-subject distance line could roughly be drawn as a horizontal line across the photograph. Consequently, image lines (i.e., rows of pixels) that run horizontally across a digital image should, in most cases, roughly represent similar subject-to-camera distances within the image scene. The GSD of each sample pixel on a given image line, therefore, should be roughly similar. In cases of very complex terrain and/or vegetation structure, stratified sampling using image lines probably would not adequately control sampling bias to scale variability. Until a method is devised to deal with scale variability in more complex images (such as using a digital overlay of concentric semicircles to delineate sampling strata rather than image lines), image-cover sampling should be confined to landscape photography where the terrain and structural diversity of the vegetation are similar to or less complex than that represented in the Whiskey Mountain time series. Photographs of linear features such as ridge lines, stream drainages, or fence rows which are viewed quartering away from the camera would also present problems for image line stratification.

\section{View Blockage Concerns}

The other principal concern when attempting to collect quantitative data from landscape photography has been view blockage by intervening features within the scene. Terrain and vegetation features may hide a substantial portion of the landscape from view. Terrain features on rangelands typically are fairly stable 
over short geologic time periods (100-150 years). Consequently, the portions of a landscape visible in a carefully matched landscape photography time series would be nearly the same for each image. In other words, view blockage by terrain would not alter between images of a time series. Growth or recession of vegetation can, however, alter which portions of a landscape are visible from image to image. These vegetation changes are represented by changes in image cover and image cover-type conversions within landscape photography. Tall foreground vegetation, however, may grow up or recede and substantially alter the visibility of landscape in the midground and background of subsequent images. If the representation of this vegetation spans across a large number of sample image lines in the midground and/or background, image-cover sampling may become biased toward the foreground. Time series revealing that a grove of trees or patch of tall brush grew up or receded in the scene foreground and thus altered the view of most of the remaining landscape are probably not suitable for image-cover analysis. In cases where vegetation growth or death altered only the view of the sky (e.g., sky to mountain mahogany image covertype conversion), view blockage is not of concern because no additional landscape became hidden or revealed.

\section{Quantifying Vegetation Change}

Although vertical canopy cover cannot be quantified from landscape photography, this paper demonstrates it is possible to estimate the image cover of vegetation by point sampling digital images derived from landscape photography. Comparing image cover within a time series of images requires that the images have similar viewpoints (camera points), view angles, and fields of view such that the images can be coregistered to each other. The process of coregistration references pixels in one image with corresponding pixels in all the other images of the time series (Richards and Jia 1999; Lillesand and Kiefer 2000). Image-cover comparisons for a time series of coregistered images, consequently, finally make it possible to quantify changes in vegetation composition and structure as they are represented in landscape photography. The reader is cautioned to recognize that image cover is not a surrogate for vertical cover measured using field techniques or by analysis of vertical remote-sensing imagery. Image cover is relevant to the image plane surface and not to the earth's surface. Field measurement of the actual dimensions of landscape portions represented by foreground, mid ground, or background image pixels allows one to evaluate whether image line stratification can effectively minimize sampling bias. These measurements may provide a rough estimate of scale variability within an image but they do not, and are not meant to, convey a physical assessment of the vegetation canopy. The accuracy of image cover-type classification, however, can and should be assessed with field data when it is possible.

\section{Classification Accuracy and Image Quality}

Comparisons of image cover using the point sampling technique described in this paper rely on the critical assumption that classification accuracy for the original photography will be similar to that of current repeat photography. This assumption may be difficult or impossible to confirm because it is unlikely that ground-truth or field data exist for any of the original or older repeat photographs. A number of factors may influence how well this assumption is actually met. Of these factors, differences in image quality and error bias associated with specific landscape features may be the most important.

Even well-archived prints and negatives degrade, thus losing contrast over time (Weinstein and Booth 1977; Reilly et al. 1988). These losses in quality may not be readily discernible by a general, macroscopic inspection of the image but likely affect the classification of individual pixels. Consequently, the image quality of the original photography and the resulting classification accuracy for this imagery will probably be poorer than that of the repeat photography. The point sampling technique described herein should only be applied to original and repeat photography of the highest available quality. A microscopic evaluation of the resolution and fine-scale contrast might aid in determining the quality of each photograph within a time series (Williams 1990).

Landscape features change over time. Vegetation represented on landscape photography, for example, may change from one cover type to another between successive photographs. Some vegetation types are more easily classified than others. Mountain mahogany, being dark in color and tree-like in shape, is easily distinguished from mountain big sagebrush; however, cured bunchgrass and bare soil have similar tones and are often difficult to differentiate in black-and-white photography. Consequently, classification of an image with substantial bare ground and grass cover may be less accurate than that of an image with mostly mountain mahogany and mountain big sagebrush cover. Unfortunately, without field data sets corresponding to both the original and repeat photography, it is impossible to ascertain the actual amount of error bias present. Collection of field data sets corresponding to current photography, however, is worthwhile to determine which vegetation types tend to have poor classification accuracy even with high quality imagery. Any error bias identified in the current photography of a time series will also likely be present in the older, poorer-quality photographs of the series. This bias will likely be greater in the poorer-quality photographs. Vegetation types exhibiting poor separability in the current photography, consequently, could then be combined into less-specific classes, which would likely improve classification accuracy and reduce error bias for all the imagery in the time series.

\section{SUMMARY AND CONCLUSIONS}

Repeat landscape photography provides scientists and natural resource managers with an opportunity to conduct landscapescale assessments of vegetation change over a much longer time span (e.g., $>145$ years) than is possible with aerial photography or satellite remote sensing. Image cover and vertical cover are entirely different measurements. Image cover describes coverage of the 2-dimensional image surface and is not meant to be treated as a surrogate for vertical plant canopy coverage of the earth's surface. Image cover can be used to quantify change that has occurred on the surfaces of a time series of coregistered landscape images. The reader is cautioned, however, to recognize that changes in image cover provide only an index of vegetation changes that have occurred on the landscape within the view frame of the time series of images and should only be interpreted in that context. Sampling bias is inherent when collecting data from oblique imagery and classification error bias 
is inherent to all remote sensing. These biases, however, can be dealt with well enough, in most cases, to allow comparative vegetation analyses using a landscape photography time series. Although point sampling of image cover is constrained by a number of limitations, this technique can provide quantitative estimates of vegetation dynamics for any area for which a suitable time series of landscape photography exists. These historical photographs are often the only records available for evaluating long-term vegetation change on many rangelands.

A principal implication of this research to natural resource managers is the ability to quantify vegetation conditions on rangelands over much longer time spans than previously possible. Management decisions concerning the current health and condition of rangelands relative to their potential future conditions should have a much firmer basis if the historical record of vegetation dynamics on these lands is longer and better documented. Quantifying the vegetation dynamics over time periods of 145 years or more will allow managers to better separate the effects of long-term environmental cycles from that of past management. A better understanding of long-term vegetation dynamics should provide all those interested in rangelands with more realistic expectations for the future health and condition of our rangelands.

\section{ACKNOWLEDGMENTS}

The authors wish to thank J. Skovlin for his thoughtful insights and encouragement, J. Mowbray and P. Meiman for their assistance in the field and in image processing, and K. Johnson, N. Harris, A. Medina, M. Seyfried, G. Anderson, R. Hunt, and several anonymous reviewers for their critical review and comments on drafts of this manuscript.

\section{LITERATURE CITED}

BISWELL, H. H. 1963. Research in wildland fire ecology in California. Proceedings of the Tall Timbers Fire Ecology Conference. Volume 2. Tallahassee, FL: Tall Timbers Research Station. p 63-97.

Blackburn, W. H., and P. T. Tueller. 1970. Pinyon and juniper invasion in black sagebrush communities in east-central Nevada. Ecology 51:841-848.

Blaisdell, J. P., R. B. MurRay, and E. D. McArthuR. 1982. Managing intermountain rangelands-sagebrush grass ranges. General Technical Report INT-134. Logan, UT: USDA Forest Service Intermountain Research Station. $41 \mathrm{p}$.

Bonham, C. D. 1989. Measurements of terrestrial vegetation. New York, NY: John Wiley and Sons. $338 \mathrm{p}$.

Cable, D. W. 1973. Fire effects in southwestern semidesert grass-shrub communities. Proceedings of the Tall Timbers Fire Ecology Conference. Volume 12. Tallahassee, FL: Tall Timbers Research Station. p 109-127.

Chadde, S. W., and C. E. Kay. 1991. Tall-willow communities on Yellowstone's Northern Range: a test of the "natural-regulation" paradigm. In: R. B. Keiter and M. S. Boyce [EDS.]. The Greater Yellowstone ecosystem: Redefining America's wilderness heritage. New Haven, CT: Yale University Press. p 231-262.

Coluins, J. B., AND C. E. Woodcock. 1996. An assessment of several linear change detection techniques for mapping forest mortality using multitemporal Landsat TM data. Remote Sensing of Environment 56:66-77.

Cooley, K. R., C. L. Hanson, and C. W. Johnson. 1988. Precipitation erosivity index estimates in cold climates. Transactions of the ASAE 31:1445-1450.

Daubenmire, R. F. 1959. Canopy coverage method of vegetation analysis. Northwest Science 33:43-64.
ElıIson, L. 1954. Subalpine vegetation of the Wasatch Plateau, Utah. Ecological Monographs 24:89-184.

Estes, J. E., D. Stow, And J. R. Jensen. 1982. Monitoring land use and land cover changes. In: C. L. Johannsen and J. L. Sanders [EDS.]. Remote sensing for resource management. Ankeny, IA: Soil Conservation Society of America. p 100-110.

GruelL, G. E. 1983. Fire and vegetative trends in the Northern Rockies: Interpretations from 1871-1982 photographs. General Technical Report INT-158. Logan, UT: USDA Forest Service Intermountain Research Station. $117 \mathrm{p}$.

Hanson, C. L. 2001. Long-term precipitation database, Reynolds Creek Experimental Watershed, Idaho, United States. Water Resources Research 37:2831-2834.

Hanson, C. L., D. Marks, and S. S. Van Vactor. 2001. Long-term climate database, Reynolds Creek Experimental Watershed, Idaho, United States. Water Resources Research 37:2839-2841.

HaRT, R. H., AND W. A. LAycock. 1996. Repeat photography on range and forest lands in the western United States. Journal of Range Management 49:60-67.

Houston, D. B. 1982. The Northern Yellowstone elk: Ecology and management. New York, NY: McGraw-Hill. $474 \mathrm{p}$.

HumphreY, R. R. 1987. Ninety years and 535 miles: Vegetation changes along the Mexican border. Albuquerque, NM: University of New Mexico Press. 448 p.

Jackson, W. H., J. Fielder, and E. Marston. 1999. Colorado, 1870-2000. Englewood, C0: Westcliffe Publishers. 224 p.

LILlesAnd, T. M., AND R. W. KIEFER. 2000. Remote sensing and image interpretation. 4th ed. New York, NY: John Wiley and Sons. $724 \mathrm{p}$.

Lunetta, R. S., And C. D. Elvidge. 1999. Remote sensing change detection: Environmental monitoring methods and applications. Ann Arbor, MI: Ann Arbor Press. $318 p$.

Martin, S. C., and R. C. Turner. 1977. Vegetation change in the Sonoran Desert region, Arizona and Sonora. Journal of the Arizona Academy of Science 12: 59-69.

Mikhall, E. M., J. S. Bethel, and J. C. McGlone. 2001. Introduction to modern photogrammetry. New York, NY: John Wiley and Sons. $479 \mathrm{p}$.

Reilly, J. M., D. W. Nishimura, K. M. Cupriks, and P. Z. Adelstein. 1988. Stability of black-and-white photographic images, with special reference to microfilm. Abbey Newsletter 12(5):83-87.

RichardS, J. A., AND X. JiA. 1999. Remote sensing digital image analysis. 3rd ed. New York, NY: Springer. $363 p$.

SAS. 1999. SAS/STAT User's Guide. Version 8. Cary, NC: SAS Institute, Inc. 752 p.

Skovlin, J. M., G. S. Strickler, J. L. Peterson, and A. W. Sampson. 2000. Interpreting landscape change in high mountains of northeastern Oregon from long-term repeat photography. General Technical Report PNW-GTR-505. Portland, OR: USDA Forest Service Pacific Northwest Research Station. 78 p.

SKovLIN, J. M., AND J. W. Thomas. 1995. Interpreting long-term trends in Blue Mountain ecosystems from repeat photography. General Technical Report PNW-GTR-315. Portland, OR: USDA Forest Service Pacific Northwest Research Station. 102 p.

StePHenson, G. R. 1977. Soil-geology-vegetation inventories for Reynolds Creek Watershed. Miscellaneous Series 42. Moscow, ID: University of Idaho Agricultural Experiment Station. $73 \mathrm{p}$.

WeBB, R. H. 1996. Grand Canyon, a century of change: Rephotography of the 1889-1890 Stanton Expedition. Tucson, AZ: University of Arizona Press. 290 p.

Weinstein, R. A., And L. Booth. 1977. Collection, use, and care of historical photographs. Nashville, TN: American Association of State and Local History. $222 \mathrm{p}$.

WilLiams, J. B. 1990. Image clarity: High resolution photography. Boston, MA: Focal Press. 30 p.

Williams, K., R. J. Hobbs, and S. P. Hamburg. 1987. Invasion of an annual grassland in Northern California by Baccharis pilularis ssp. consanguinea. Oecologia 72:461-465.

Wolf, P. R., And B. A. DeWitt. 2000. Elements of photogrammetry with applications in GIS. 3rd ed. New York, NY: McGraw-Hill. 608 p. 